\title{
Development of symbiotic yoghurt and biological evaluation (New Zealand White Rabbits) of its functional properties
}

\author{
Alice de Souza RIBEIRO ${ }^{1 \star}$ (D), Maritiele Naissinger da SILVA ${ }^{1}$, Bruna Lago TAGLIAPIETRA ${ }^{1}$, \\ Berilo de Souza BRUM JÚNIOR², Mariane Lobo UGALDE², Neila Silvia Pereira dos Santos RICHARDS ${ }^{1}$
}

\begin{abstract}
Functional foods are those that bring benefits to human health beyond nutrition such as the prevention of cardiovascular diseases, allergies and intestinal problems. Among the functional foods highly consumed worldwide, yogurt is highlighted, especially in the probiotic and symbiotic versions. The aim of this study was to use the Jerusalem artichoke tuber flour (Helianthus tuberosus L.) as a new prebiotic source for the development of functional yogurt. The identification and quantification of the fructans of the Jerusalem artichoke flour was performed and later yoghurt formulations were elaborated. These yogurts were submitted to analyses of centesimal composition, shelf life and sensorial evaluation. For the biological evaluation, a symbiotic yogurt formulation was chosen (the best accepted in sensorial evaluation) and included in the feed of New Zealand white rabbits, in the growth and final phase. The in vivo experiment had three distinct groups (control group, probiotic group and symbiotic group). At the end of 50 days of experiment, the animals were euthanized and submitted to the serological and cecal microbiota evaluation. Through this study, the prebiotic/bifidogenic capacity of Jerusalem artichoke flour was evidenced.
\end{abstract}

Keywords: functional foods; biological evaluation; Helianthus tuberosus L.; symbiotic yogurt.

Practical Application: New prebiotic/ functional ingredient alternative for application in fermented dairy products.

\section{Introduction}

Since 1991, there has been food regulation called "Foods for Specified Health Use" (FOSHU). In this context, it is possible to observe a growing consumer demand for food that offers health benefits, such as disease prevention and, consequently, an improvement in their quality of life (Santos et al., 2006).

In order to meet this food profile, the food industry, science and technology have advanced in the use of functional ingredients (Pinto \& Paiva, 2010). Functional foods are found virtually in all food categories, however products are not homogeneously scattered over all segments of the market. The development and commerce of these products is rather complex, expensive and risky, as special requirements should be answered. Besides potential technological obstacles, legislative aspects, as well as consumer demands need to be taken into consideration when developing functional food. In particular, consumer acceptance has been recognized as a key factor to successfully negotiate market opportunities (Siró et al., 2008).

Yogurts, cereals, fermented milk and other functional products are trend in this niche market. This is due to the benefits these foods bring to human health. For instance, aid in curing or prevention of diseases such as those affecting the cardiovascular system, many types of allergies and intestinal problems, as well as the growing concern with health and well-being, and the growing scientific evidence of the relationships existing between diet and health (Raud, 2008).

Moreover, as an ingredient used in functional food formulations, the so-called prebiotics stand out. They are defined as nondigestible food ingredients that beneficially affect the organism by selectively stimulating the growth and/or activity of bacteria in the colon. This is a substance that modifies the composition of the colonic microbiota in such a way that the bacteria with health promotion potential become the predominant majority (Capriles et al., 2005).

Prebiotics promote the survival or persistence of probiotic strains, enhance defense mechanisms of the host, increase resistance to various health disorders, and modify human gastrointestinal tract troubles (Singh \& Singh, 2010; Bañuelos et al., 2008; Mountzouris et al., 2006).

On the other hand, probiotics are live microorganisms which when administered in adequate amounts and frequency confer a health benefit on the host (Food and Agriculture Organization of the United Nations, 2001; Roberfroid et al., 2010). The beneficial influence of probiotics on the human intestinal microbiota includes factors such as antagonistic effects, competition and immunological effects, resulting in increased resistance against pathogens (Uyeda et al., 2016). 
A product in which a probiotic and a prebiotic are combined is called symbiotic. Interaction between the probiotic and the prebiotic in vivo might be favored by an adaptation of the probiotic to the prebiotic substrate prior to consumption, but the bacteria should be able to survive in the food (Moroti et al., 2014).

Among probiotic and symbiotic functional foods, dairy products, especially fermented milks, are market leaders and are considered research priorities in many countries. The growing appreciation of functional foods around the world is promoting innovations in food products and stimulating the consumption of foods with nutritional and therapeutic value (Kumar et al., 2015).

Helianthus tuberosus L. (Asteraceae), popularly known in Brazil as tupinambor and worldwide as Jerusalem artichoke, is a perennial herb originating from eastern North America. It was introduced and extensively cultivated in temperate areas for edible tubers. Helianthus Tuberosus L. has high stem, large leaves, bright yellow flowers similar to sunflowers and potato tubers. As a source of inulin, tubers have been used as a popular medicine for the treatment of diabetes and rheumatism as well as for a variety of pharmacological activities such as laxative, diuretic, spermatogenic, stomach and tonic (Pan et al., 2009).

The Jerusalem artichoke accumulates similar levels of fructan to the roots of chicory $(16-20 \%)$ and is one of the most interesting plants for the industrial production of inulin, since it is possible to cultivate it at low cost, with low application of fertilizers in any type of soil and conditions cold weather (Franck, 2000). The fructans, considered prebiotics, are able to resist the hydrolysis of digestive enzymes in the part of the human gastrointestinal tract and, therefore, they have a low caloric value for humans $\left(1.5 \mathrm{kcal} \mathrm{g}^{-1}\right)$ and perform similar functions to dietary fiber (Genta et al., 2009).

The fructans are the main storage carbohydrate of H. tuberosus L., representing between 70 and $80 \%$ of the dry matter of the tubers, which ranges from 18 to $25 \%$ (Losavio et al., 1997). This species is considered as one of the most important candidates for use as a raw material for the industrial production of biological fructose and inulin (Baldini et al., 2004; Kays \& Kultur, 2005).

Fructans of the inulin type (fructooligosaccharides, oligofructose and inulin) are considered prebiotics, composed of $\beta$-linked fructosyl units (2-1) with or without terminal $\mathrm{D}$-glucose at the reducing end. They have different degrees of polymerization (DP) and can originate naturally as native components in many plants or derive by biochemical/enzymatic techniques (Bañuelos et al., 2008; Genta et al., 2009).

In view of the above, the aim of this work was to elaborate symbiotic yogurt, using as a prebiotic ingredient the tuber of "Tupinambor" (Helianthus tuberosus L.), and as probiotic the culture of Bifidobacterium lactis HN019. Furthermore, this study also identifies and quantifies the fructans in the prebiotic flour, characterises physicochemically, perform the shelf-life of the yogurt and analyse the sensory acceptance and then evaluate its symbiotic efficiency by means of biological assay in vivo.

\section{Materials and methods}

\subsection{Obtaining Jerusalem artichoke flour}

The Jerusalem artichoke (Helianthus tuberosus L.) was commercially purchased in the form of flour.

\subsection{Identification and quantification of fructans in Jerusalem artichoke flour}

The chromatographic profile of sugars was determined by high performance liquid chromatography (HPLC) in a VARIAN chromatograph model Pro Satr 410. The following chromatographic conditions were used: chromatographic column Bio Rad no. 125-0128; column Bio Rad AMINEX HPX-87P $(300 \times 7.8 \mathrm{~mm})$; column temperature at $80^{\circ} \mathrm{C}$; refractive index detector (RID); eluent deionized water purified on ion-exchange column, filtered on a $0.22 \mu \mathrm{m}$ pore polyethylene filter and then degassed in an ultrasonic bath; volume of the injected sample $20 \mu \mathrm{L}$. The samples were filtered through a membrane filter (Durapore) in PVDF, with $0.22 \mu \mathrm{m}$ pore and $13 \mathrm{~mm}$ diameter. The results were compared to Sigma standards, analysed under the same conditions described above. The determination of the sugar concentration was calculated in relation to standard solutions at $1 \%$.

\subsection{Production of yogurts}

The raw material used for the preparation of the yogurts was ultra high temperature (U.H.T.) whole milk, the lyophilized commercial starter cultures were: Streptococcus thermophilus and Lactobacillus delbrueckii subsp. bulgaricus (traditional culture) and the probiotic culture was Bifidobacterium lactis HN019, both from Danisco ${ }^{\circledR}$.

A completely randomized experimental design with factorial $2^{2}$ was used to evaluate the effect of the different components used to prepare the yogurts on the characteristics of the same, with two independent variables and a control treatment, totaling five treatments and three replicates. The independent variables were the amount of sugar ( 80 and $100 \mathrm{~g}$ ) and Jerusalem artichoke flour (50 and $70 \mathrm{~g}$ ).

The formulations were as follows: standard (probiotic yogurt - $1 \%$ probiotic culture $+8 \%$ sugar), F1 (simbiotic yogurt $5 \%$ tupinambor flour/ $10 \%$ sugar), F2 (simbiotic yogurt $5 \%$ tupinambor flour / 8\% sugar), F3 (simbiotic yogurt 7\% tupinambor flour / 8\% sugar) e F4 (simbiotic yogurt 7\% tupinambor flour / 10\% sugar).

\subsection{Centesimal composition and shelf life}

The determination of the centesimal composition (moisture, ashes, lipids, protein and carbohydrates) of yogurts was performed according to the Association of Official Analytical Chemists (2007). The total dietary fiber and its soluble and insoluble fractions were determined by the enzymatic-gravimetric method 991.43 (Association of Official Analytical Chemists, 2007). For the evaluation of shelf life of the yogurts, the microbial count of bifidobacteria in the modified MRS culture medium was performed with the addition of $0.2 \%(\mathrm{~m} / \mathrm{v})$ lithium and $0.3 \%(\mathrm{~m} / \mathrm{v})$ dicloxacillin, besides monitoring the titratable 
acidity and pH (Digimed, São Paulo, Brasil). Serial dilutions of the samples were performed, plating in triplicate in depth, using $0.1 \mathrm{~mL}$ aliquots. The plates were incubated in anaerobiosis at $37^{\circ} \mathrm{C}$ for 72 hours (Vinderola \& Reinheimer, 2000).

\subsection{Sensory analysis}

A total number of 76 untrained judges, consisting of yogurt consumers, of both genders and aged between 18 and 50, participated in the study. The samples temperature was $5{ }^{\circ} \mathrm{C}$. The analyses were performed in a sensory analysis laboratory, in individual booths and with white lighting. Acceptance testing was applied through a structured hedonic scale of nine points, (1- I greatly disliked to 9-I greatly liked), as described by Lawless \& Heymann (2010). A preference testing by ordering from the most preferred to the least preferred, as suggested by Dutcosky (2011), was also performed.

The untrained judges received a portion of each sample (approximately $20 \mathrm{~mL}$ ) in white plastic cups encoded with three-digit numbers, in a balanced and randomized manner, accompanied by a glass of water to make the blank between samples.

The project was approved by the Research Ethics Committee of the Federal University of Santa Maria (UFSM), under the Certificate of Presentation for Ethical Appreciation (CAAE) 56769116.9.0000.5346.

\subsection{In vivo experiment}

A number of $40 \mathrm{New}$ Zealand white rabbits with initial age of 35 days and weighing on average $917 \mathrm{~g}$ were used. The rabbits were housed in individual cages with semi-automatic feeder and automatic nipple drinking fountain. From 35 to 40 days of age, the animals went through the adaptation period. The rabbits were obtained through the Laboratory of Teaching, Research, Extension and Production (LEPEP) - Cuniculture of the Federal Institute Farroupilha - Júlio de Castilhos. The experiment was conducted with the approval of the Committee on Ethics in the Use of Animals under protocol number 9412161017.

Subsequently, the animals were distributed in a completely randomized experimental design with three treatments of 10 replicates each, for a total of 30 experimental units. The treatments were composed by different experimental groups: control group (CG) - commercial feed only, probiotic group (PG) - commercial feed + probiotic yogurt and symbiotic group (SG) - commercial feed + symbiotic yogurt. The yogurts were given to the animals through gavage, and $10 \mathrm{~mL}$ were administered per animal per day.

At the end of the 50-day experiment, the animals were euthanized through cranial concussion followed by exsanguination, where blood collection was performed for centrifugation and separation of serum and blood plasma for serological analysis and the collection of cecal material for microbiological evaluation.

Furthermore, serological analysis of total cholesterol, HDL cholesterol (High Density Lipoproteins), LDL cholesterol (Low Density Lipoproteins), triacylglycerols, and glucose were determined using colorimetric enzyme kits and the reading was performed in a spectrophotometer. On the other hand, for the microbiological determination of the cecal content, $1.0 \mathrm{~g}$ of the intestinal content was weighed and transferred aseptically with a sterile spatula into a test tube containing $9.0 \mathrm{~mL}$ of diluent. Then, the necessary, decimal dilutions were performed for the plating in depth using MRS agar medium plus lithium chloride and dicloxacillin, according to the methodology proposed by Casteele et al. (2006).

\subsection{Statistical analysis}

The data were submitted to the univariate analysis of variance and its averages compared by the Tukey test at $5 \%$ of significance, using Statistica software version 9.1 (Statsoft Inc., Tulsa - OK, USA).

\section{Results and discussion}

\subsection{Identification and quantification of fructans in the Helianthus tuberosus L. flour}

According to the fructan chromatographic profile of the Helianthus tuberosus L. flour (Table 1), it can be observed that it has a considerable content of inulin (44.44\%), when compared to the yacon potato, for instance, which has in general terms from 60 to $70 \%$ of inulin and fructooligosaccharides (Vilhena et al., 2000). Inulin is a fructooligosaccharide which, unlike most others, is not digested in the stomach. Its caloric contribution is rather small: about 1.5 kilocalories per gram, against $4 \mathrm{kcal} / \mathrm{g}$ of sugar and $9 \mathrm{kcal} / \mathrm{g}$ of fat (Rensis \& Souza, 2008).

According to Hua et al. (2007), the values of inulin found in the tubers of Helianthus tuberosus can often exceed 50\% of their composition, reaching values of $50,20 \%$ and 78,16 as already presented by other authors (Tiengtam et al., 2015; Afoakwah et al., 2015). Inulin values may vary according to plant variety. Petkova et al. (2014) found values between 40.5 and $68.7 \%$ of inulin for different varieties of Jerusalem artichoke.

\subsection{Centesimal composition and shelf life}

Table 2 shows the values of the centesimal composition and dietary fiber of the standard yoghurt and the different symbiotic yogurt formulations.

The moisture, ash, lipids, protein, carbohydrate and dietary fiber contents presented little difference between the formulations, since the variation of sugar and flour ingredients of Jerusalem artichoke had little influence on the bromatological composition of the formulations. The similar contents of ashes, proteins and lipids of the formulations can be explained because sugar and

Table 1. Identification and quantification of fructans in the Helianthus tuberosus L. flour.

\begin{tabular}{cc}
\hline Components & Results $\left(\mathrm{g} 100 \mathrm{~g}^{-1}\right)$ \\
\hline Fructose & $0.67 \pm 0.01^{\star}$ \\
Glucose & $1.66 \pm 0.01$ \\
Sucrose & $9.24 \pm 0.01$ \\
Fructooligosaccharide & $0.38 \pm 0.01$ \\
Inulin & $44.44 \pm 0.01$ \\
\hline
\end{tabular}

${ }^{*}$ Values are the mean of the triplicate, followed \pm standard deviation. 
inulin (Jerusalem artichoke flour) are exempt of these nutrients in their physicochemical composition (Universidade Estadual de Campinas, 2011), without altering the nutritional status of the products. Santos et al. (2014) found similar data by adding inulin in yogurt formulations. All yogurt formulations meet Brazilian legislation in force (Brasil, 2000) and according to resolution GMC 47/97 yogurts are classified as whole given its fat content (Brasil, 1997).

Moreover, in relation to functional properties, it is possible to emphasise the dietary fiber fraction, in which dietary recommendations for daily fiber consumption are 20-40 g per day (World Health Organization, 1998). The Brazil National Health Surveillance Agency (ANVISA) recommends that the product registered in the category of functional foods and/or health must present the claim according to the list of approved claims. Food fiber source should contain in the portion of the product ready for consumption a minimum of $3 \mathrm{~g}$ of fiber if the food is solid and $1.5 \mathrm{~g}$ if it is liquid (Brasil, 2002). Therefore, the Jerusalem artichoke flour may have the functional claim (fiber source), when added to the food products, in this case the yoghurt, provided it is in accordance with its respective portion established by the RDC no. 359 of ANVISA (Brasil, 2003).

The stability of the yogurts during their refrigeration storage was evaluated by the parameters of $\mathrm{pH}$, acidity and microbial counts for 30 days (Tables 3 and 4), where measurements were performed every 15 days.

The average initial $\mathrm{pH}$ of the yogurts was 4.93 but by the end of the 30 days of storage, it dropped to 4.77 . The $\mathrm{pH}$ reduction during storage can be explained by the lactose consumption by the lactic bacteria present in yogurts. Moreover, it is also possible to affirm that the Jerusalem artichoke flour had no influence on this parameter. On the other hand, acidity had stable values throughout the storage period.

When evaluating the results of Table 4 , it can be observed that the yoghurts presented counts of lactic bacteria and bifidobacteria compatible with the Technical Regulation of Identity and Quality of Fermented Milks during the storage period. The regulation recommends the total lactic acid bacteria count of $10^{7}$ colony forming units per gram $(\mathrm{CFU} / \mathrm{g})$ of the product and $10^{6} \mathrm{CFU} / \mathrm{g}$ for bifidobacteria (Brasil, 2007).

In the case of functional foods, the minimum viable quantity for probiotics should be in the range of $10^{8}$ to $10^{9} \mathrm{CFU} / \mathrm{g}$ in the daily recommendation of the product ready for consumption. This corresponds to the consumption of $100 \mathrm{~g}$ of a product containing $10^{6}$ to $10^{7} \mathrm{CFU} / \mathrm{g}$, i.e. from 6 to $7 \log \mathrm{CFU} / \mathrm{g}$. This result is also in accordance with the amount recommended by several authors so that the probiotic microorganisms produce the desired physiological effect (Jelen \& Lutz, 1998).

According to the results, the prebiotic effect of the Jerusalem artichoke flour is evidenced, where at the end of the 30 days of refrigerated storage $\left(5 \pm 1^{\circ} \mathrm{C}\right)$ the symbiotic yogurt presented one logarithmic cycle more than the probiotic yogurt. This result matches with data obtained from previous research in which bifidobacteria counts were evaluated in fermented milks with and without inulin addition and found average values of 5-6 $\log \mathrm{CFU} / \mathrm{g}$ without inulin addition and 6-7 $\log \mathrm{CFU} / \mathrm{g}$ with inulin addition (Gallina et al., 2011; Trento et al., 2009). In the yogurts added with Jerusalem artichoke flour, the bifidobacteria count remained constant throughout 30 days of refrigerated storage $\left(5 \pm 1{ }^{\circ} \mathrm{C}\right)$, whereas in the standard yogurt without the presence of Jerusalem artichoke flour there was a decrease of one logarithmic cycle after 30 days of storage.

Table 2. Centesimal composition of symbiotic yogurt formulations.

\begin{tabular}{ccrrrrr}
\hline Fraction $(\mathrm{g} / 100 \mathrm{~g})$ & \multicolumn{1}{c}{ Standard } & \multicolumn{1}{c}{ F1 } & F2 & F3 & F4 & VC $(\%)$ \\
\hline Moisture & $85.03^{\mathrm{a}} \pm 0.00$ & $84.56^{\mathrm{a}} \pm 0.03$ & $82.66^{\mathrm{c}} \pm 0.00$ & $82.36^{\mathrm{c}} \pm 0.11$ & $83.03^{\mathrm{b}} \pm 0.04$ & 1.80 \\
Ashes & $0.74^{\mathrm{ab}} \pm 0.45$ & $0.73^{\mathrm{ab}} \pm 0.02$ & $0.72^{\mathrm{b}} \pm 0.05$ & $0.76^{\mathrm{ab}} \pm 0.03$ & $0.77^{\mathrm{a}} \pm 0.04$ & 2.63 \\
Lipids & $3.09^{\mathrm{a}} \pm 0.25$ & $3.19^{\mathrm{a}} \pm 0.11$ & $3.16^{\mathrm{a}} \pm 0.10$ & $3.48^{\mathrm{a}} \pm 0.21$ & $3,44^{\mathrm{a}} \pm 0.08$ & 1.32 \\
Protein & $2.96^{\mathrm{c}} \pm 0.26$ & $3.45^{\mathrm{b}} \pm 0.04$ & $3.59^{\mathrm{ab}} \pm 0.19$ & $4.15^{\mathrm{a}} \pm 0.27$ & $4,10^{\mathrm{a}} \pm 0.19$ & 5.78 \\
Carbohydrates & $8.81^{\mathrm{a}} \pm 0.00$ & $8.23^{\mathrm{b}} \pm 0.00$ & $8.36^{\mathrm{b}} \pm 0.00$ & $9.11^{\mathrm{a}} \pm 0.00$ & $9,39^{\mathrm{a}} \pm 0.00$ & 1.51 \\
Dietary fiber & $1.93^{\mathrm{a}} \pm 0.00$ & $1.81^{\mathrm{b}} \pm 0.00$ & $1.83^{\mathrm{b}} \pm 0.00$ & $2.00^{\mathrm{a}} \pm 0.00$ & $2,06^{\mathrm{a}} \pm 0.00$ & 1.51 \\
\hline
\end{tabular}

Different letters in the same line present significant difference at the level of $5 \%(\mathrm{p}<0.05)$. Reading: Standard (probiotic yogurt $-1 \%$ probiotic culture $+8 \%$ sugar), F1 (simbiotic yogurt 5\% tupinambor flour/ 10\% sugar), F2 (simbiotic yogurt 5\% tupinambor flour / 8\% sugar), F3 (simbiotic yogurt 7\% tupinambor flour / 8\% sugar) and F4 (simbiotic yogurt 7\% tupinambor flour / 10\% sugar), VC (coefficient of variation).

Table 3. $\mathrm{pH}$ and titratable acidity values of the yogurt formulations during storage.

\begin{tabular}{|c|c|c|c|c|c|c|}
\hline \multirow{2}{*}{ Product } & \multicolumn{3}{|c|}{$\mathrm{pH}$} & \multicolumn{3}{|c|}{ Titratable acidity } \\
\hline & Day 01 & Day 15 & Day 30 & Day 01 & Day 15 & Day 30 \\
\hline$S$ & $4.93^{\mathrm{aA}} \pm 0.01$ & $4.85^{\mathrm{bB}} \pm 0.00$ & $4.78^{\mathrm{aA}} \pm 0.00$ & $0.6^{\mathrm{aA}} \pm 0.00$ & $0.7^{\mathrm{aA}} \pm 0.00$ & $0.7^{\mathrm{aA}} \pm 0.0 \mathrm{C}$ \\
\hline F1 & $4.92^{\mathrm{aB}} \pm 0.01$ & $4.87^{\mathrm{abA}} \pm 0.00$ & $4.78^{\mathrm{aA}} \pm 0.00$ & $0.7^{\mathrm{aA}} \pm 0.00$ & $0.7^{\mathrm{aA}} \pm 0.00$ & $0.7^{\mathrm{aA}} \pm 0.0 \mathrm{C}$ \\
\hline F2 & $4.93^{\mathrm{aA}} \pm 0.01$ & $4.87^{\mathrm{abA}} \pm 0.01$ & $4.77^{\mathrm{aA}} \pm 0.01$ & $0.7^{\mathrm{AA}} \pm 0.00$ & $0.7^{\mathrm{aA}} \pm 0.00$ & $0.7^{\mathrm{aA}} \pm 0.0 \mathrm{c}$ \\
\hline F3 & $4.94^{\mathrm{aA}} \pm 0.01$ & $4.87^{\mathrm{abA}} \pm 0.01$ & $4.77^{\mathrm{aA}} \pm 0.01$ & $0.7^{\mathrm{aA}} \pm 0.00$ & $0.7^{\mathrm{aA}} \pm 0.00$ & $0.7^{\mathrm{aA}} \pm 0.0 \mathrm{C}$ \\
\hline F4 & $4.92^{\mathrm{aB}} \pm 0.01$ & $4.87^{\mathrm{aA}} \pm 0.01$ & $4.77^{\mathrm{aA}} \pm 0.01$ & $0.7^{\mathrm{aA}} \pm 0.00$ & $0.7^{\mathrm{aA}} \pm 0.00$ & $0.7^{\mathrm{aA}} \pm 0.0 \mathrm{c}$ \\
\hline
\end{tabular}

Different lowercase letters in the same row and uppercase in the same column present a significant difference at the $5 \%$ level (p <0.05). Reading: $\mathrm{S}$ - standard (probiotic yogurt - $1 \%$ probiotic culture + 8\% sugar), F1 (simbiotic yogurt 5\% tupinambor flour/ 10\% sugar), F2 (simbiotic yogurt 5\% tupinambor flour / 8\% sugar), F3 (simbiotic yogurt 7\% tupinambor flour / 8\% sugar) e F4 (simbiotic yogurt $7 \%$ tupinambor flour / $10 \%$ sugar) 


\subsection{Sensorial evaluation}

The sensorial evaluation of this work had the aim to reach the ideal formulation of symbiotic yogurt for subsequent experiment in vivo. All the yoghurts evaluated presented average acceptance allocated between the hedonic terms "greatly disliked" and "greatly liked".

According to Table 5, for all attributes the standard formulation (probiotic, without Jerusalem artichoke flour) was the one that obtained the highest scores. However, for the other formulations added of Jerusalem artichoke flour, no significant

Table 4. Microbial counts values measured on days 1, 15 and 30 of storage at $5 \pm 1{ }^{\circ} \mathrm{C}$.

\begin{tabular}{ccccc}
\hline \multirow{2}{*}{ Product } & \multirow{2}{*}{ Determinations } & \multicolumn{3}{c}{ Counts (Log CFU/g) } \\
\cline { 3 - 5 } & & Day 1 & Day 15 & Day 30 \\
\hline \multirow{2}{*}{ S } & Lactic acid bacteria & 9.15 & 8.20 & 6.51 \\
& Bifidobacteria & 8.0 & 7.93 & 6.06 \\
\multirow{2}{*}{ F2 } & Lactic acid bacteria & 9.53 & 8.32 & 7.53 \\
& Bifidobacteria & 9.20 & 9.00 & 8.06 \\
\multirow{2}{*}{ F3 } & Lactic acid bacteria & 9.52 & 9.10 & 7.08 \\
& Bifidobacteria & 8.83 & 8.00 & 7.00 \\
\multirow{2}{*}{ F4 } & Lactic acid bacteria & 9.20 & 8.83 & 7.52 \\
& Bifidobacteria & 9.0 & 8.16 & 8.03 \\
& Lactic acid bacteria & 9.22 & 9.05 & 7.07 \\
& Bifidobacteria & 9.50 & 8.86 & 8.23 \\
\hline
\end{tabular}

CFU/g - Colony Forming Unit per gram of product. Reading: S - standard (probiotic yogurt $-1 \%$ probiotic culture $+8 \%$ sugar), F1 (simbiotic yogurt $5 \%$ tupinambor flour/ 10\% sugar), F2 (simbiotic yogurt 5\% tupinambor flour / 8\% sugar), F3 (simbiotic yogurt $7 \%$ tupinambor flour / $8 \%$ sugar) e F4 (simbiotic yogurt $7 \%$ tupinambor flour / 10\% sugar).

Table 5. Results of the sensorial evaluation regarding the acceptance test of five yogurt formulations.

\begin{tabular}{cccccc}
\hline Samples & Color & Flavor & Taste & Texture & $\begin{array}{c}\text { Overall } \\
\text { Appearance }\end{array}$ \\
\hline S & $8.17^{\mathrm{a}}$ & $7.91^{\mathrm{a}}$ & $8.20^{\mathrm{a}}$ & $8.09^{\mathrm{a}}$ & $8.25^{\mathrm{a}}$ \\
F1 & $6.74^{\mathrm{b}}$ & $7.02^{\mathrm{b}}$ & $6.81^{\mathrm{b}}$ & $6.77^{\mathrm{b}}$ & $6.93^{\mathrm{b}}$ \\
F2 & $6.81^{\mathrm{b}}$ & $7.10^{\mathrm{b}}$ & $6.68^{\mathrm{b}}$ & $6.90^{\mathrm{b}}$ & $6.75^{\mathrm{b}}$ \\
F3 & $6.75^{\mathrm{b}}$ & $6.66^{\mathrm{b}}$ & $6.40^{\mathrm{b}}$ & $6.74^{\mathrm{b}}$ & $6.74^{\mathrm{b}}$ \\
F4 & $7.02^{\mathrm{b}}$ & $6.93^{\mathrm{b}}$ & $6.58^{\mathrm{b}}$ & $7.08^{\mathrm{b}}$ & $7.13^{\mathrm{b}}$ \\
VC (\%) & 23.32 & 23.21 & 26.38 & 23.64 & 23.64 \\
\hline
\end{tabular}

Averages in the same column with different envelopes differ significantly $(\mathrm{p}<0.05)$; VC - coefficient of variation. 1 = I really disliked it, 2 = I really disliked it, $3=$ I disliked it, 4 = indifferent, $5=\mathrm{I}$ liked it, $6=\mathrm{I}$ liked it a lot and $7=\mathrm{I}$ liked it a lot. Reading: $\mathrm{S}$ - standard (probiotic yogurt $-1 \%$ probiotic culture $+8 \%$ sugar), F1 (simbiotic yogurt $5 \%$ tupinambor flour/ 10\% sugar), F2 (simbiotic yogurt 5\% tupinambor flour / 8\% sugar), F3 (simbiotic yogurt $7 \%$ tupinambor flour / $8 \%$ sugar) e F4 (simbiotic yogurt $7 \%$ tupinambor flour / 10\% sugar). difference was observed, but in the preference test between the yogurts added of Jerusalem artichoke flour, the yogurt F1, with $5 \%$ of flour and $10 \%$ of sugar, was preferred by the untrained judges and, therefore, was the formulation defined to be used in the biological assay.

\subsection{In vivo evaluation}

\section{Weight gain}

At the beginning of the experiment, the animals weighed an average of $0.917 \mathrm{~kg}$ and at the end $2.348 \mathrm{~kg}$, representing an average gain of $1.431 \mathrm{~kg}$. The groups submitted to the consumption of probiotic and symbiotic yogurts presented an increase in weight gain, whereas the control group obtained a final average weight of $2.170 \mathrm{~kg}$, compared to 2.470 and $2.403 \mathrm{~kg}$ of the probiotic and symbiotic groups, respectively. Nonetheless, this difference was a consequence of the increase in caloric intake by the groups that consumed yogurt and commercial feed in relation to those who consumed commercial feed only.

\section{Serological evaluation}

Table 6 shows the values of total cholesterol, HDL, LDL, triglycerides and glucose of the different animal groups. These results indicate a reduction in total cholesterol levels in relation to the control where the symbiotic yogurt group obtained a value of $40.33 \mathrm{mg} / \mathrm{dL}$ against $50.66 \mathrm{mg} / \mathrm{dL}$ from the control group. There was no significant difference for the HDL levels, however for the LDL levels the group fed with probiotic yogurt presented lower levels when compared to the control and symbiotic groups.

The simultaneous use of probiotics and prebiotics has been studied as a way to improve the viability of probiotic microorganisms and to potentiate the control of individual cholesterol levels attributed to probiotics and prebiotics (Liong \& Shah, 2006).

The prebiotic action of inulin using yogurt-fed rabbits as a biological model is not usual in the literature, but studies such as Maertens et al. (2004) analysed this process by adding $2 \%$ of inulin or oligofructose to the feeding of nine week old rabbits. After ten days submitted to this, the rabbits were euthanized for further evaluation of their intestinal content. However, the presence of $\beta$-fructan (2-1) at the level of the small intestine (ileum) was not detected in rabbits that were fed with control feed. On the other hand, rabbits fed with feed added with inulin or phospholigosaccharides (POS) presented lower degradation rates $-49.2 \%$ and $35.3 \%$, respectively. Yet, at the level of the large intestine (cecum) and fecal matter of all rabbits, including those fed with inulin and POS, no type of fructan was detected, which

Table 6. Results of serological evaluation of rabbits in differents groups.

\begin{tabular}{|c|c|c|c|c|c|}
\hline Group & $\begin{array}{c}\text { Cholesterol } \\
(\mathrm{mg} / \mathrm{dL})\end{array}$ & $\begin{array}{c}\text { HDL } \\
(\mathrm{mg} / \mathrm{dL})\end{array}$ & $\begin{array}{c}\mathrm{LDL} \\
(\mathrm{mg} / \mathrm{dL})\end{array}$ & $\begin{array}{l}\text { Triglycerides } \\
(\mathrm{mg} / \mathrm{dL})\end{array}$ & $\begin{array}{l}\text { Glucose } \\
(\mathrm{mg} / \mathrm{dL})\end{array}$ \\
\hline Control & $50.66^{\text {a* }} \pm 4.16$ & $28.0^{\mathrm{a}} \pm 1.52$ & $26.0^{\mathrm{a}} \pm 1.73$ & $55.66^{\mathrm{a}} \pm 2.30$ & $136.66^{a} \pm 0.57$ \\
\hline Probiotic & $45.33^{\mathrm{ab}} \pm 4.04$ & $27.33^{\mathrm{a}} \pm 0.57$ & $18.66^{\mathrm{b}} \pm 2.08$ & $46.66^{\mathrm{b}} \pm 2.23$ & $114.33^{\mathrm{b}} \pm 4.16$ \\
\hline Simbiotic & $40.33^{b} \pm 2.08$ & $29.66^{\mathrm{a}} \pm 4.05$ & $27.33^{\mathrm{a}} \pm 2.88$ & $42.0^{\mathrm{b}} \pm 3.46$ & $88.0^{c} \pm 1.00$ \\
\hline VC (\%) & 7.83 & 11.10 & 8.89 & 5.59 & 3.09 \\
\hline
\end{tabular}

${ }^{*}$ Averages in the same column with different envelopes differ significantly $(\mathrm{p}<0.05)$; VC - coefficient of variation. 
confirms its complete fermentation by the microbial flora located therein and consequently its prebiotic effect.

In addition, other studies, such as the one conducted by Rossi et al. (2008), who used probiotic cultures in soybean water extract and obtained a lipid-lowering effect, that is, a control of cholesterol levels in rabbits (total cholesterol $=-18.4 \%$; $\mathrm{HDL}-\mathrm{C}=+17.8 \%$ ) and mice (non-HDL cholesterol $=-23.2 \%$ ).

From the results presented in Table 6, we can observe that there was a significant difference $(\mathrm{p}<0.05)$ in the triglycerides where the control group obtained a value of $55.66 \mathrm{mg} / \mathrm{dL}$, in comparison to $42 \mathrm{mg} / \mathrm{dL}$ of the symbiotic yogurt group. The control value is quite similar to the one found by Torres et al. (2009), who evaluated this parameter in 42 day old rabbits and obtained the value of $59.7 \mathrm{mg} / \mathrm{dL}$. This difference in triglyceride contents in both control and symbiotic groups may indicate an influence of the symbiotic product also in triglyceride levels.

Rodrigues et al. (2004), by verifying glucose in New Zealand white rabbits at 31 days of age fed exclusively with feed obtained levels of $130.64 \mathrm{mg} / \mathrm{dL}$. In the present study, under the same dietary conditions, the glucose value of the control group was $136.66 \mathrm{mg} / \mathrm{dL}$, whereas the symbiotic yogurt group had significantly lower levels $(88.0 \mathrm{mg} / \mathrm{dL})$.

Overall, the decrease in the levels of cholesterol, LDL, triglycerides and serological glucose in animals receiving symbiotic yogurt when compared to the control animals is due to the presence of inulin, which being a soluble fiber that cannot be digested by the intestine, causes a reduction in glycaemia and in the concentration of free fatty acids and plasma cholesterol levels. In addition, soluble fibers also "steal" bile salts and thus contribute to lowering cholesterol levels (Capriles et al., 2005; Stefe et al., 2008; Uyeda et al., 2016).

\section{Evaluation of the cecal microbiota}

As can be observed in Figure 1, animals receiving symbiotic yogurt had a higher bifidobacteria count $\left(9.93 \log 10 \mathrm{~mL}^{-1}\right.$ ) when compared to animals receiving only probiotic yogurt

\section{Bifidobacteria count}

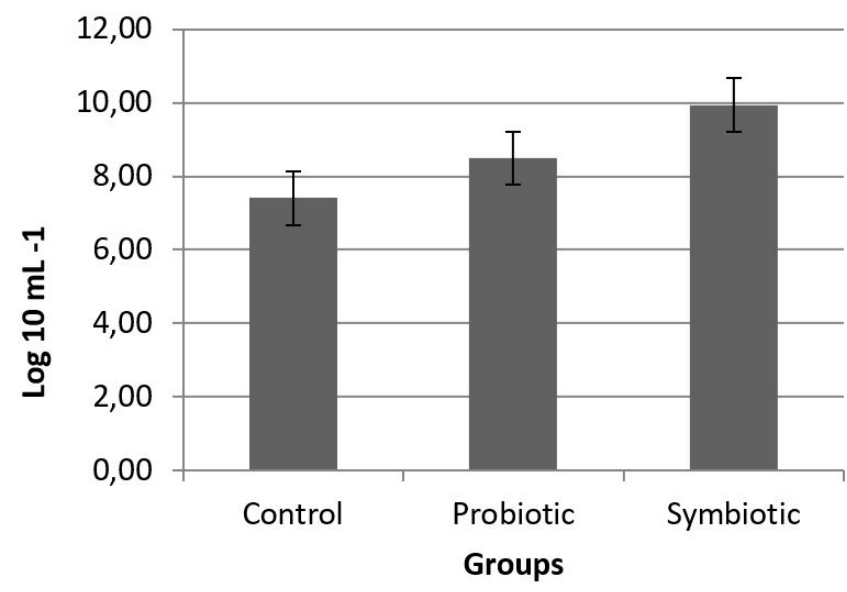

Figure 1. Cecal microbiota from habbits in differents treatments.
(8.49 $\left.\log 10 \mathrm{~mL}^{-1}\right)$ and with the control group $\left(7.41 \log 10 \mathrm{~mL}^{-1}\right)$, which is accordance with the bifidogenic potential of the Jerusalem artichoke tuber flour.

Lima et al. (2018), when studying supplementation with oligosaccharides and fructooligosaccharides in mice obtained values of bifidobacteria in the contents of the ascending colon of $9.0 \log 10 \mathrm{~mL}^{-1}$. Similarly, Lemos et al. (2010) by adding prebiotics in the diet of the mice found values of $10.0 \log 10 \mathrm{~mL}^{-1}$ of bifidobacteria in the intestinal contents. However, Rodrigues et al. (2012) used yacon flour as a prebiotic source in yogurts and obtained a higher bifidobacteria count when purchased with the probiotic product. As previously discussed, there are no studies with prebiotic yoghurt supplementation in rabbits in the literature, yet, the comparison with the biological model most used in research is valid.

\section{Conclusion}

Through this study, it can be concluded that the use of Jerusalem artichocke (Helianthus tuberosus L.) flour as a prebiotic ingredient in yoghurt performs a bifidogenic function, modulating the microbial flora and conferring health benefits, speciality with a significant reduction in the cholesterol and glucose levels in the animals evaluated, according to the serological and microbiological parameters evaluated.

\section{Acknowledgements}

The authors would like to thank the Coordination for Higher Education Staff Development (Coordenação de Aperfeiçoamento de Pessoal de Nível Superior, Capes, Brazil).

\section{References}

Afoakwah, N. A., Dong, Y., Zhao, Y., Xiong, Z., Owusu, J., Wang, Y., \& Zhang, J. (2015). Characterization of Jerusalem artichoke (Helianthus tuberosus L.) powder and its application in emulsion-type sausage. Food Science and Technology, 64(1), 74-81. https://doi.org/10.1016/j. lwt.2015.05.030.

Association of Official Analytical Chemists - AOAC. (2007). Official Methods of Analysis of the AOAC (18th ed., 2005, Current Though Revision 2). Arlington: AOAC.

Baldini, M., Danuso, F., Turi, M., \& Vannozzi, G. P. (2004). Evaluation of new clones of Jerusalem artichoke (Helianthus tuberosus L.) for inulin and sugar yield from stalks and tubers. Industrial Crops and Products, 19(1), 25-40. http://dx.doi.org/10.1016/S0926-6690(03)00078-5.

Bañuelos, O., Fernández, L., Corral, J. M., Valdivieso-ugarte, M., Adrio, J. L., \& Velasco, J. (2008). Metabolism of prebiotic products containing beta (2-1) fructan mixtures by two Lactobacillus strains. Anaerobe, 14(3), 184-189. http://dx.doi.org/10.1016/j.anaerobe.2008.02.002. PMid:18434219.

Brasil. Agência Nacional de Vigilância Sanitária - ANVISA. (2002). Lista de alegações de propriedade funcional aprovadas para alimentos com alegações de propriedades funcionais e / ou de saúde, novos alimentos / ingredientes, substâncias bioativas e probióticos. Diário Oficial da República Federativa do Brasil.

Brasil. Agência Nacional de Vigilância Sanitária - ANVISA. (2003, December 23). Regulamento técnico de porções de alimentos embalados para fins de rotulagem nutricional (Resolução n 359, 
de 23 de dezembro de 2003). Diário Oficial da República Federativa do Brasil.

Brasil. Ministério da Agricultura e Abastecimento. (1997). Regulamento Técnico de Identidade e Qualidade de Leites Fermentados. Brasília: DIPOA.

Brasil. Ministério da Agricultura e Abastecimento. (2000, November 13). Secretaria de Defesa Agropecuária. Departamento de Inspeção de Produtos de Origem Animal. Padrões de Identidade e Qualidade de Leites Fermentados (Resolução n5, 13 de Novembro de 2000). Diário Oficial da República Federativa do Brasil.

Brasil. Ministério da Agricultura, Pecuária e Abastecimento. (2007, November 23). Portaria no 46, de 23 de novembro de 2007: regulamento técnico de identidade e qualidade (PIQ) de leites fermentados. Diário Oficial da República Federativa do Brasil.

Capriles, V. D., Silva, K. E. A., \& Fisberg, M. (2005). Prebióticos, probióticos e simbióticos: nova tendência no mercado de alimentos funcionais. Nutrição Brasil, 4(6), 327-335.

Casteele, S., Vanheuverzwijn, T., Ruyssen, T., Van Assche, P., Swings, J., \& Huys, G. (2006). Evaluation of culture media for selective enumeration of probiotic strains of lactobacilli and bifidobacteria in combination with yoghurt or cheese starters. International Dairy Journal, 16(12), 1470-1476. http://dx.doi.org/10.1016/j.idairyj.2005.12.002.

Dutcosky, S. D. (2011). Análise sensorial de alimentos (3. ed.). Curitiba: Champagnat.

Food and Agriculture Organization of the United Nations - FAO, World Health Organization - WHO. (2001). Evaluation of health andnutritional properties of poder milk and live lactic acid bacteria. Córdoba.

Franck, A. M. E. (2000). Inulin and oligofructose. In G. Gibson, \& F. Angus (Eds.), LFRA ingredient handbook: prebiotics and probiotics (pp. 1-18). Surrey: Leatherhead PublishinCg.

Gallina, D. A., Alves, A. T. S., Trento, F. K. H. S., \& Carusi, J. (2011). Caracterização de leites fermentados com e sem adição de probióticos e prebióticos e avaliação da viabilidade de bactérias láticas e probióticas durante a vida de prateleira. UNOPAR Científica. Ciências Biológicas e da Saúde, 13(4), 239-244.

Genta, S., Cabrera, W., Habib, N., Pons, J., Carillo, I. M., Grau, A., \& Sánchez, S. (2009). Yacon syrup: beneficial effects on obesity and insulin resistance in humans. Clinical Nutrition, 28(2), 182-187. http://dx.doi.org/10.1016/j.clnu.2009.01.013. PMid:19254816.

Hua, Y., Liu, B., \& Zhao, Z. (2007). Patent No. WO/2008/ 011811. Biological production of fuels. China.

Jelen, P., \& Lutz, S. (1998). Functional milk and dairy products. In Mazza G. Functional foods: biochemical and processing aspects. Lancaster: Technomic Publishing Company.

Kays, S. J., \& Kultur, F. (2005). Genetic variation in Jerusalem artichoke (Helianthus tuberosus L.) Flowering date and duration. HortScience, 40, 1675-1678.

Kumar, H., Salminen, S., Verhagen, H., Rowland, I., Heimbach, J., Bañares, S., Young, T., Nomoto, K., \& Lalonde, M. (2015). Novel probiotics and prebiotics: road to the market. Current Opinion in Biotechnology, 32, 99-103. http://dx.doi.org/10.1016/j.copbio.2014.11.021. PMid:25499742.

Lawless, H. T., \& Heymann, H. (2010). Sensory evaluation of food: principles and practices (2nd ed.). London: Springer. http://dx.doi. org/10.1007/978-1-4419-6488-5.

Lemos, A. C. G., Capaldi, M. L. P., Santos, R., \& Pastore, G. M. (2010). Morphometric study of intestinal mucosa in rats suplemented with prebiotics. In $8^{\circ}$ Simpósio Latino Americano de Ciência dos Alimentos. Salvador.
Lima, G. C., Vieira, V. C. C., Cazarin, C. B. B., Ribeiro, R. D. R., Bogusz, S. Jr., Albuquerque, C. L., Vidal, R. O., Cardoso, C. C. No., Yamada, Á. T., Augusto, F., \& Maróstica, M. R. Jr. (2018). Fructooligosaccharide intake promotes epigenetic changes in the intestinal mucosa in growing and ageing rats. European journal of nutrition, 57(4), 14991510. PMid:28324207.

Liong, M. T., \& Shah, N. P. (2006). Effects of a Lactobacillus casei synbiotic on serum lipoprotein, intestinal microflora, and organic acids in rats. Journal of Dairy Science, 89(5), 1390-1399. http:// dx.doi.org/10.3168/jds.S0022-0302(06)72207-X. PMid:16606710.

Losavio, N., Lamascese, N., \& Vonella, A. V. (1997). Water requirements and nitrogen fertilization in Jerusalem artichoke (Helianthus tuberosus L.) grown under Mediterranean conditions. Acta Horticulturae, (449), 205-209. http://dx.doi.org/10.17660/ActaHortic.1997.449.28.

Maertens, L., Aerts, J. M., \& De Boever, J. (2004). Degradation of dietary oligofructose and inulin in the gastro-intestinal tract of the rabbit and the effects on caecal $\mathrm{pH}$ and volatile fatty acids. World Rabbit Science, 12, 235-246.

Moroti, C., Magri, L. F. S., Souza, J. C. B., Mattos, D. B. S., Costa, M. R., \& Sivieri, K., (2014). Potencial da utilização de alimentos probióticos, prebióticos e simbióticos na redução de colesterol sanguíneo e glicemia. UNOPAR Científica. Ciências Biológicas e da Saúde, 11(4), 63-67. http://dx.doi.org/10.17921/2447-8938.2009v11n4p\%25p.

Mountzouris, K. C., Balaskas, C., Fava, F., Tuohy, K. M., Gibson, G. R., \& Fegeros, K. (2006). Profiling of composition and metabolic activities of the colonic microflora of growing pigs fed diets supplemented with prebiotic oligosaccharides. Anaerobe, 12(4), 178-185. http:// dx.doi.org/10.1016/j.anaerobe.2006.04.001. PMid:16731014.

Pan, L., Sinden, M. R., Kennedy, A. H., Chai, H., Watson, L. E., Graham, T. L., \& Kinghorn, A. D. (2009). Bioactive constituents of Helianthus tuberosus (Jerusalem artichoke). Phytochemistry Letters, 2(1), 15-18. http://dx.doi.org/10.1016/j.phytol.2008.10.003.

Petkova, N., Ivanov, I., Denev, P., \& Pavlov, A. (2014). Bioactive substance and free radical scavenging activities of flour from Jerusalem Artichoke (Helianthus tuberosus L.) Tubers - a comparative study. Turkish Journal of Agricultural and Natural Sciences, 1(2), 1773-1778.

Pinto, A. L. D., \& Paiva, C. L. (2010). Desenvolvimento de uma massa funcional pronta para tortas utilizando o método de Desdobramento da Função Qualidade (QFD). Food Science and Technology, 30(1), 36-43. http://dx.doi.org/10.1590/S0101-20612010000500007.

Raud, C. (2008). Functional foods: the new frontier of the food industryDanone and Nestlé strategies for the brazilian yogurt market. Revista de Sociologia e Politica, 16(31), 85-100. http://dx.doi.org/10.1590/ S0104-44782008000200008.

Rensis, C.M.V.B., \& Souza, P.F.F. (2008). Análise sensorial de iogurtes light elaborados com adição de fibras de inulina e oligofrutose. Revista Uberaba, 5, 68-72.

Roberfroid, M., Gibson, G. R., Hoyles, L., McCartney, A. L., Rastall, R., Rowland, I., Wolvers, D., Watzl, B., Szajewska, H., Stahl, B., Guarner, F., Respondek, F., Whelan, K., Coxam, V., Davicco, M. J., Léotoing, L., Wittrant, Y., Delzenne, N. M., Cani, P. D., Neyrinck, A. M., \& Meheust, A. (2010). Prebiotic effects: metabolic and health benefits. British Journal of Nutrition, 104(Suppl 2), 1-63. http://dx.doi. org/10.1017/S0007114510003363. PMid:20920376.

Rodrigues, F. C., Castro, A. S., Rodrigues, V. C., Fernandes, S. A., Fontes, E. A., Oliveira, T. T., Martino, H. S., \& Luces Ferreira, C. L. F. (2012). Yacon flour and Bifidobacterium longum modulate bone health in rats. Journal of Medicinal Food, 15(7), 664-670. http:// dx.doi.org/10.1089/jmf.2011.0296. PMid:22510044.

Rodrigues, F. C., Oliveira, T. T., Nagem, T. J., Stringheta, P. C., \& Ferreira D. B. Jr. (2004). Efeito de naringenina asssociada com leite 
de cabra sobre o metabolismo lipídico de coelhos. Revista Chilena de Nutrición, 21(1), 177-182.

Rossi, E. A., Cavallini, D. C. U., Carlos, I. Z., Vendramini, R. C., Dâmaso, A. R., \& Valdez, G. F. (2008). Intake of isoflavone-supplemented soy yogurt fermented with Enterococcus faecium lowers serum total cholesterol and non-HDL cholesterol of hypercholesterolemic rats. European Food Research and Technology, 228(2), 275-282. http:// dx.doi.org/10.1007/s00217-008-0932-9.

Santos, E.F., Jacobucci, H.B., Queiroz, M.M., Dias, N.F.G.P. (2006). Alimentos funcionais. Revista de Pesquisas Biológicas da UNIFEV, 1, 13-19.

Santos, K. A., Santos, E. F., Manhani, M. R., Sanches, F. L. F. Z., Ballard, C. R., \& Novello, D. (2014). Avaliação das características sensoriais e físico-químicas de iogurte adicionado de inulina. Revista UNIABEU, 7(15), 1-11.

Singh, R. S., \& Singh, R. P. (2010). Production of fructooligosaccharides from inulin by endoinulinases and their prebiotic potential. Food Technology and Biotechnology, 48, 435-450.

Siró, I., Kápolna, E., Kápolna, B., \& Lugasi, A. (2008). Functional food. Product development, marketing and consumer acceptance - A review. Appetite, 51(3), 456-467. http://dx.doi.org/10.1016/j. appet.2008.05.060. PMid:18582508.

Stefe, C. A., Alves, M. A. R., \& Ribeiro, R. L. (2008). Probióticos, prebióticos e simbióticos - artigo de revisão. Saúde e Ambiente em Revista, 3(1), 16-33.

Tiengtam, N., Khempaka, S., Paengkoum, P., \& Boonanuntanasarn, S. (2015). Effects of inulin and Jerusalem artichoke (Helianthus tuberosus) as prebiotic ingredients in the diet of Nile tilapia
(Orechronis niloticus). Animal Feed Science and Technology, 207, 120-129. http://dx.doi.org/10.1016/j.anifeedsci.2015.05.008.

Torres, R. J. A., Maia, M., Noronha, L., Farah, M. E., Luchini, A., Brik, D., Muccioli, C., \& Précoma, D. B. (2009). Evaluation of choroid and sclera early alterations in the hypercholesterolemic rabbits. Histologic and histomorphometric study. Arquivos Brasileiros de Oftalmologia, 72(1), 68-74. http://dx.doi.org/10.1590/S0004-27492009000100014. PMid:19347126.

Trento, F. K. H. S., Moreno, I., Gallina, D. A., Silva, A. T., Zacarchenco, P. B., \& Liserre, A. M. (2009) Contagem de bactérias lácticas e probióticas em diferentes formulações de leites fermentados contendo ou não probióticos, após o processamento e durante a estocagem. In $26^{\circ}$ Congresso Nacional de Laticínios (pp. 1-7). Juiz de Fora: EPAMIG.

Universidade Estadual de Campinas - UNICAMP. (2011). Tabela Brasileira de Composição de Alimentos - TACO. Campinas: UNICAMP/NEPA.

Uyeda, M., Del Buonom, H. C., Gonzaga, M. F. N., \& Carvalho, F. L. O. (2016). Probióticos e prebióticos: benefícios acerca da literatura. Revista de Saúde UniAGES, 1(1), 33-57.

Vilhena, S. M. C., Câmara, F. L. A., \& Kakihara, S. T. (2000). O cultivo do yacon no Brasil. Horticultura Brasileira, 18(1), 5-8. http://dx.doi. org/10.1590/S0102-05362000000100002.

Vinderola, C. G., \& Reinheimer, J. A. (2000). Enumeration of Lactobacillus casei in the presence of L. acidophilus, bifdobacteria and lactic starter bacteria in fermented dairy products. International Dairy Journal, Barking, 10(4), 271-275. http://dx.doi.org/10.1016/S09586946(00)00045-5.

World Health Organization - WHO. (1998). Obesity preventing and managing the global epidemic: report of a WHO Consultation of Obesity. Geneva: WHO. 